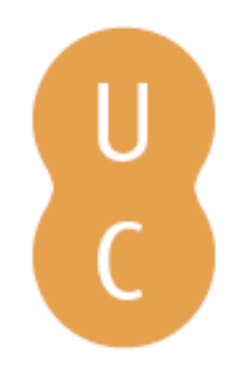

\title{
pompalina
}

\section{Perception and risk of exposure to xylene by pathologic anatomy students}

\begin{tabular}{ll} 
Autor(es): & $\begin{array}{l}\text { Teixeira, M. Dias; Rangel, R.; Teixeira, A. Dias; Domingues, V.; Olea, S. } \\
\text { de Abajo; Delerue-Matos, C. }\end{array}$ \\
Publicado por: & $\begin{array}{l}\text { Imprensa da Universidade de Coimbra; International Academy of Legal } \\
\text { Medicine }\end{array}$ \\
$\begin{array}{ll}\text { URL } \\
\text { persistente: }\end{array}$ & URI:http://hdl.handle.net/10316.2/31792 \\
DOI: & DOI:http://dx.doi.org/10.14195/978-989-26-0173-1_33 \\
Accessed : & 26-Apr-2023 13:23:22 \\
\hline
\end{tabular}

A navegação consulta e descarregamento dos títulos inseridos nas Bibliotecas Digitais UC Digitalis, UC Pombalina e UC Impactum, pressupõem a aceitação plena e sem reservas dos Termos e Condições de Uso destas Bibliotecas Digitais, disponíveis em https://digitalis.uc.pt/pt-pt/termos.

Conforme exposto nos referidos Termos e Condições de Uso, o descarregamento de títulos de acesso restrito requer uma licença válida de autorização devendo o utilizador aceder ao(s) documento(s) a partir de um endereço de IP da instituição detentora da supramencionada licença.

Ao utilizador é apenas permitido o descarregamento para uso pessoal, pelo que o emprego do(s) título(s) descarregado(s) para outro fim, designadamente comercial, carece de autorização do respetivo autor ou editor da obra.

Na medida em que todas as obras da UC Digitalis se encontram protegidas pelo Código do Direito de Autor e Direitos Conexos e demais legislação aplicável, toda a cópia, parcial ou total, deste documento, nos casos em que é legalmente admitida, deverá conter ou fazer-se acompanhar por este aviso.

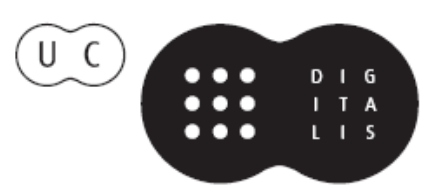




\section{Duarte Nuno Vieira Anthony Busuttil \\ Denis Cusack • Philip Beth}
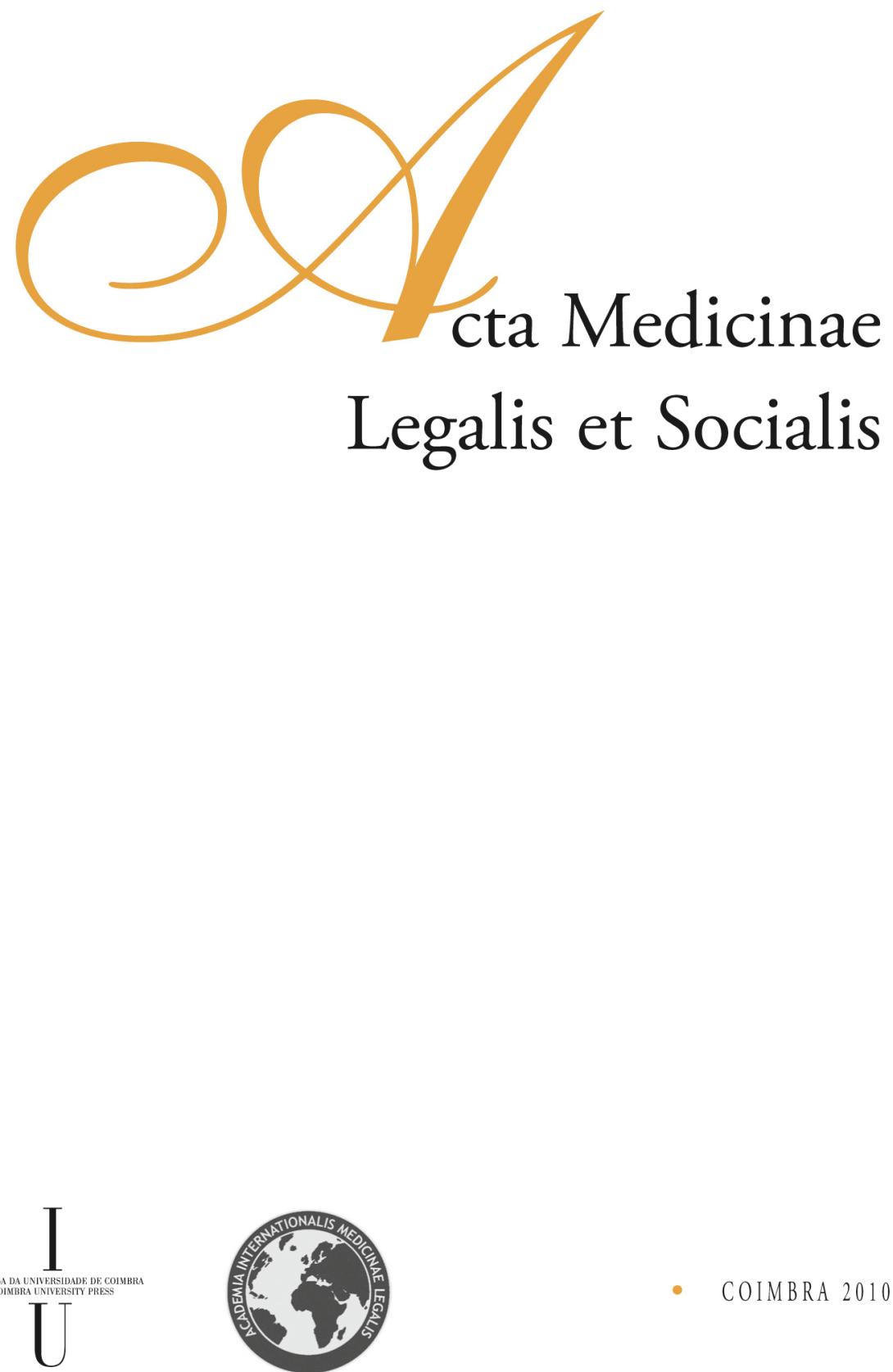
M. Dias Teixeira ${ }^{2,3}$, R. Rangel ${ }^{3,4}$, A. Dias Teixeira ${ }^{5}$, V. Domingues ${ }^{1}$, S. de Abajo Olea ${ }^{2}$, C. Delerue-Matos ${ }^{1}$

${ }^{1}$ Requimte, Engineering Institute of Oporto, Portugal

${ }^{2}$ Biomedical Sciences Department, University of Léon, Spain

${ }^{3}$ Health Technologies Research Center, Polytechnic Health Institute of the North, Gandra PRD, Portugal

4 Forensic Toxicology Department, North Branch of the Portuguese National Institute of Legal Medicine, Oporto, Portugal

5 Engineering Institute of Oporto, Portugal

\title{
PERCEPTION AND RISK OF EXPOSURE TO XYLENE BY PATHOLOGIC ANATOMY STUDENTS
}

\begin{abstract}
This study intends to assess the perceived and real risk of occupational exposure to xylene by students in bachelor degree of pathologic anatomy, cytology and thanatology. A questionnaire was produced and validated (Likert scale) applied to a sample of 217 students in higher education. Air samples were collected using activated charcoal cartridges. The quantification of the three xylene isomers (ortho, meta, and para) was performed by GC-FID.

With respect to perception and the classification of the risk of exposure to xylene for $35.9 \%$ of individuals corresponds to moderate risk (MR), 30.8\% of high risk (HR), $28.2 \%$ of low risk (LR) and $5.1 \%$ of no risk (NR). The handling of this compound without gloves for $59.9 \%$ of students in MR, $21.5 \%$ for VR, $16.3 \%$ for LR and $2.3 \%$ of NR. For $56.7 \%$ of students there is danger of exposure to xylene. Xylene concentrations in laboratories environment were found at the range of 113.15-714.93 ppm and vary along of the week. The average concentration of total xylenes was $169.38 \pm 76.15 \mathrm{ppm}$, which is below the Threshold Limit Values - Time Weighted Average (TLV-TWA). The highest occupational exposure occurred at slide mounting stage of the histological processing.
\end{abstract}

\section{Introduction}

Laboratory is inherently potentially dangerous environments and there will be always a level of risk associated with the work undertaken. In laboratories (where a variety of hazards exist) the workers must be closely supervised at all times. People who work in histology laboratory and related disciplines are at risk from exposure to risk agents. This risks can be traumatic for individuals, as well as extremely toxic (Buesa, 2007; Vecchio, Sasco and Cann, 2003).

The chemical hazards depending on the specific compound has the potential to poison (toxics, including carcinogens, teratogens and mutagens), burn (corrosive), irritate, produce allergenic reactions, explode, ignite or asphyxiate. They can affect us by inhalation, skin contact and ingestion. So may pose immediate consequences for the health or longterm (Buesa, 2007). The presence of technicians of pathologic anatomy, cytologic and thanatologic, it is essential to ensure a smooth functioning of a laboratory of pathology and cytological (Ferrand and Bernard, 1995). Inexperienced workers are persons at special 
risk (including undergraduate students and school pupils on "work experience" schemes), deserves special attention. The adequate processing of tissues and body fluids require the use of chemical substances. A hazardous chemical by the Occupational Safety and Health Administration (OSHA), is a substance that may cause health effects in short- or longterm exposed employees, based on statistically significant evidence from at least one study conducted using established scientific principles (OSHA, 1994). It is certainly a broad definition that applies to all, or almost all of the chemicals typically used in laboratories. During academic training, the students need to handle chemicals, which can be classified according to Portuguese legislation, Portaria n. ${ }^{\circ}$ 732-A/96 as extremely flammable, highly flammable, flammable, highly toxic, toxic, harmful, corrosive, sensitizing, irritant, toxic for reproduction, dangerous to the environment, explosive, incendiary, mutagenic and carcinogenic, putting in danger the man and the environment (Ministério da Economia, Ministério da Saúde and Ministério do Ambiente, 1996).

In pathology and histology laboratories, the chemicals more used are xylene, formaldehyde, the acids and ethanol, among other toxic substances that easily contaminate the air (Roy D. R., 1999), as well generate hazardous waste (xylene) (Environmental Protection Agency, 2000). The xylene is an important component of the routine, almost indispensable in laboratory and is often perceived by the technicians as a source of problems for the health(Agency for Toxic Substances and Disease Registry, 1999, 2005). The theme of the risk, as part of job security is recent and is not studied completely. The perception of risk interferes in behavior and with the preventive measures against the procedures that can cause injury and / or accidents (Sanders and McCormick, 1993). The main purpose of the psychological approach to Shrader-Frechette, focuses on responding to questions on the perception and acceptability of risks, after considering the views expressed by individuals, to which you are requested assessments of certain activities and / or dangerous technologies (Shrader-Frechette, 1985).

This study intends to assess the perceived and real risk of occupational exposure to xylene by students in bachelor degree of pathologic anatomy, cytologic and thanatologic.

\section{Materials and Methods}

\section{Questionnaire}

A descriptive survey was conducted during the period November of 2007 to May 2008 and information was collected on a sample of 217 students who attended randomly selected superior institute schools in Gandra (Portugal).

The questionnaire was extensive, but only a small portion of all the items will be used.

The question asked for a rating of global attitude to exposure occupational to xylene in Pathological Anatomy Laboratory, on a four-step category based in Likert scale. The categories on this group varied from "no risk" to "must risk". In questionnaire socio-demographic data (gender, age, and academic level) were collected, and consisted in sources of danger: classification of risk of exposure to xylene; classification of risk of manipulation of xylene without gloves; 


\section{Study Population}

All students in the sample received an anonymous self-administered questionnaire and a letter explaining the purpose of the study, advising that they were under no obligation to complete the questionnaire, explaining that the information obtained would remain confidential, that the research team was available to provide further clarification of questions when necessary.

The students were divided into four academic groups:

- First Degree: no classes in histology laboratory

- Second Degree: 2 hours per week in histology laboratory

- Third Degree: 21 hours per week in histology laboratory

- Fourth Degree: 2 hours per week in histology laboratory

\section{Statistical analysis}

The internal consistency reliability coefficients using Cronbach's alpha or scale reliability coefficient from SPSS 16.0.1 for Windows software (SPSS Inc, Chicago, Illinois, USA) were examined. The intraclass correlation coefficient was evaluated by Pearson's test and Mann-Whitney test. For all statistical tests a p-value below 0.05 was considered significant.

\section{Air of Pathological Anatomy Laboratory Sampling}

Air sampling was performed for the $3^{\text {rd }}$ October of 2008 to $15^{\text {th }}$ of January of 2009. Air samples (129) were collected using activated charcoal cartridges, between 9:00 am and 5:00 pm, during the 21 hours a week of academic training, all days except Tuesday and week-end.

Personal air values were measured by means of passive air samplers (SKC solid adsorbent badges, inc. catalog number 530-11) equipped with of charcoal (cartridge (SKC coconut shell charcoal adsorbent sample tubes, inc. catalog number 226-01)). As reported in the SKC certificate of quality, these cartridges are calibrated at $25^{\circ} \mathrm{C}$. Confounding factors of temperature and humidity in determination of chemicals were not relevant. The passive-spread samplers were positioned in proximity to the respiratory airways at the collar of each subject during the daily work day (between 9:00 am and 5:00 pm). The sampling times were of around $15 \mathrm{~min}$. The samples were analyzed using a GC Chrompack CP-9000 Series equipped with a flame ionization detector (FID) and capillary column VF-5ms, $30 \mathrm{~m}$ x $0.225 \mathrm{~mm}$ ID, film $0.25 \mu \mathrm{m}$.

\section{Results}

\section{Validation}

The used questionnaire was first tested in a pilot scale for testing feedback by format to enhance clarity, reliability of responses and validation. No modifications were necessary to the final questionnaire. 


\section{Demographics}

Two hundred and fourteen undergraduated students of pathologic anatomy, citologic and thanatologic $\left(1^{\text {st }}, 2^{\text {nd }}, 3^{\text {rd }}\right.$ and $\left.4^{\text {th }}\right)$ respondents were enrolled. There were $32(14.7 \%)$ men and 185 (85.3\%) women, the students characteristics are presented in Table I.

The test Komolgorov-Smirnov (KS) revealed that all variables do not have a normal distribution (the value of $\mathrm{D}$ ranges between 0.156 and 0.452 ; Lilliefors $\alpha=5 \%$ ).

\section{Risk perception}

In classifying the risk of exposure to xylene in the laboratory of histology, $35.9 \%$ of the sample survey classifies it as being of moderate risk, $30.8 \%$ of very risk; little risk of $28.2 \%$ and $5.1 \%$ of no risk. Although, the test Mann, revealed that there are no significant differences between the $1^{\text {st }}$ year and $3^{\text {rd }}$ year $(p=0.084 ; \alpha=0.05)$, and the $2^{\text {nd }}$ and $4^{\text {th }}$ grade $(\mathrm{p}=0.239 ; \alpha=0.05)$. However there are significant differences between students of $1^{\text {st }}$ year and $2^{\text {nd }}$ year $(p=0.003 ; \alpha=0.05) ; 1^{\text {st }}$ year and $3^{\text {rd }}$ year $(\mathrm{p}=0.049 ; \alpha=0.05) 1^{\text {st }}$ year and $4^{\text {th }}$ year $(\mathrm{p}=0.002 ; \alpha=0.05) ; 2^{\text {nd }}$ year and $3^{\text {rd }}$ year $(p=0.000 ; \alpha=0.05) ; 3^{\text {rd }}$ year and $4^{\text {th }}$ year $(p=0.000 ; \alpha=0.05) ;($ Table II).

The use of Personal Protective Equipment (PPE) is in itself an increase of demands for workers, often causing discomfort and other undesirable effects, especially when used for long periods of time. When handling chemicals, it is recommended that gloves with the right kind of material be used to protect the worker from accidental spills or contamination. The use of PPE's contributed to reducing the exposure of all or part of the risks, as the reduction of accidents at work. The classification of the risk of xylene manipulation without gloves: for $59.9 \%$ of students is much risk, $21.5 \%$ moderate risk, $16.3 \%$ of low risk and 2.3\%. The Mann-Whitney test showed that there are no significant differences between the $1^{\text {st }}$ and ${ }^{4 \text { th }}$ grade $(p=0.055 ; \alpha=$ $0.05)$. Although there are significant differences between students of $1^{\text {st }}$ year and $2^{\text {nd }}$ year $(p=0.000 ; \alpha=0.05) ; 1^{\text {st }}$ year and $3^{\text {rd }}$ year $(p=0.006 ; \alpha=0.05) ; 1^{\text {st }}$ year and $4^{\text {th }}$ year $(\mathrm{p}=0.000 ; \alpha=0.05) ; 2^{\text {nd }}$ year and $3^{\text {rd }}$ year $(\mathrm{p}=0.000 ; \alpha=0.05) ; 2^{\text {nd }}$ year and $4^{\text {th }}$ year $(p=0.001 ; \alpha=0.05) ; 3^{\text {rd }}$ year and $4^{\text {th }}$ year $(p=0.000 ; \alpha=0.05)$ (Table III).

The personal monitor air measurements were compared to the values of atmospheric air at the three histological stages (histological staining, slide mounting and chemical waste disposal. Figure I shows the results obtained for the ambient air contaminants. Each area represents the mean of 129 measurements of total xylenes. The mean of each gas was determined separately, and subsequently, these values were summed to arrive at data shown in Figure I.

The concentrations obtained for the three xylene isomers was show to vary along of the week. Xylene concentrations were found at the range of 113.15-714.93 ppm. The average concentration of total xylenes was $169.38 \pm 76.15$ ppm (mean \pm SD), which is below the Threshold Limit Values - Time Weighted Average (TLV-TWA). Significantly higher levels of xylene, were found during at histological staining and slide mounting. The highest occupational exposure occurred at slide mounting stage of the histological processing. 


\section{Discussion}

The questionnaire showed an excellent Cronbach's alpha or scale reliability coefficient of 0.943 (lower bound of $95 \%$ CI of 0.935 ) indicating good internal consistency of the test instrument. This was probably due to a large number of items in the questionnaire.

Risks tend to be perceived differently for one's own person compared with others (Söjberg L. and Engelberg E., 2009). The degree of risk attributed to increases in the light of an increasing frequency academic year, except for students enrolled in $3^{\text {rd }}$ grade. The majorities of students in $1^{\text {st }}$ grade has no opinion or attach little risk, the $2^{\text {nd }}$ grade low or moderate risk, the $3^{\text {rd }}$ grade considered little risk or no risk and the degree of risk assigned by the students and $4^{\text {th }}$ grade ranges from low risk to much risk. Authors in another studies search similar tendencies for personal and general risks and risk taking for oneself and others(Stone E. R., Yates A. J. and Caruthers A. S., 2002).

Regarding the perception of risk to xylene is largely aware of the risk to which they are subject however the perception of students is higher in the $2^{\text {nd }}$ and $4^{\text {th }}$ grade. Regardless of exposure time there is always risk.

A higher level of Pathological Anatomy Laboratory air contamination was found in the slide mounting area with greater concentrations of xylenes. The values founded were higher than 100 ppm (established in standard NP 1796:2007).

\section{Conclusion}

The results demonstrate that the manipulation of organic solvents, which includes xylenes, requires, correct and adequate information, to the students and lab workers in general, about the chemical and health risks, since, roughly $25 \%$ of students had no opinion on the risk of exposure to xylene, which may indicate lack in the consciousness of the danger. Students should have more information about dangerousness of those chemical substances. The individual perception of risk is a critical component of the behavior of students.

Implementation of measures to improve indoor air quality in order to reduce occupational exposure, as there are environmental concentrations exceeds the TLVTWA, mainly in the stages of staining and slides mounting.

Concentrations above 100 ppm may endanger the student's health, mainly assigned to develop their curricular activity for 21 hour in this laboratory, i.e. $24 \%$ of the population; Strategies for prevention which includes environmental monitoring and biomonitoring should be periodically.

\section{References}

AGENCY FOR TOXIC SUBSTANCES AND DISEASE REGISTRY. ToxFAQs ${ }^{\mathrm{TM}}$ for Formaldehyde (Formaldehido). Atlanta, GA, 1999.

AGENCY FOR TOXIC SUBSTANCES AND DISEASE REGISTRY. ToxFAQs ${ }^{\mathrm{TM}}$ for Xileno (Xylene). Atlanta, GA, 2005.

BUESA RJ. Histology safety: now and then. Annals of Diagnostic Pathology, 11: 334-339, 2007. 
ENVIRONMENTAL PROTECTION AGENCY. Healthy Hospitals: Environmental Improvements Through Environmental Accounting Washington. Washington, 2000.

FERRAND J, BERNARD F. L'enseignement en formation continue des techniques appliques à l'anatomie pathologique et la cytopathologie. Revue française des laboratoires, 280: 55 $57,1995$.

MINISTÉRIO DA ECONOMIA, MINISTÉRIO DA SAÚDE, MINISTÉRIO DO AMBIENTE. Aprova o Regulamento para a Notificação de Substâncias Químicas e para a Classificação, Embalagem e Rotulagem de Substâncias Perigosas. Diário da República, 1996.

OSHA. Hazard Communication. In: 1910.1200 (ed). Toxic and Hazardous Substances. Washington: Department of Labor, 1994.

ROY DR. Histology and pathology laboratories. Chemical hazard prevention and medical/ health surveillance. Official Journal of the American Association of Occupational Health Nurses, 47: 199-205, 1999.

SANDERS MS, MCCORMICK EJ. Human Factors In Engineering and Design. New York, NY: McGraw-Hill, 1993.

SHRADER-FRECHETTE KS. Risk Analysis and Scientific Method: Methodological and Ethical Problems with Evaluating Societal Hazards Boston: Reidel, 1985.

SÖJBERG L, ENGELBERG E. Attitudes to Economic Risk Taking, Sensation Seeking and Values of Business Students Specializing in Finance Journal of Behavioral Finance, 20: 33-43, 2009.

STONE ER, YATES AJ, CARUTHERS AS. Risk Taking in Decision Making for Others Versus the Self. Journal of Applied Social Psychology,, 32: 1797-1824, 2002.

VECCHIO D, SASCO AJ, CANN CI. Occupational risk in health care and research. American Journal of Industrial Medicine, 43: 369-397, 2003.

\begin{tabular}{|lccc|}
\hline $\begin{array}{l}\text { Characteristic } \\
\text { Gender }\end{array}$ & N & $\%$ & Mean ISD \\
Male & 32 & 14.7 & \\
Female & 185 & 85.3 & \\
Academic Level & & & \\
$\mathbf{1}^{\text {st }}$ & 62 & $29 \%$ & \\
$\mathbf{2}^{\text {nd }}$ & 49 & $23 \%$ & \\
$\mathbf{3}^{\text {rd }}$ & 49 & $23 \%$ & \\
$\mathbf{4}^{\text {th }}$ & 54 & $25 \%$ & \\
Age & & & $22 \pm 2$ \\
\hline
\end{tabular}

Table I - Selected Characteristics of the Study Population 


\begin{tabular}{|ccccc|}
\hline & no risk (\%) & little risk (\%) & moderate risk (\%) & much risk (\%) \\
$\mathbf{1}^{\text {st }}$ Year & 14.3 & 21.4 & 57.1 & 7.1 \\
$\mathbf{2}^{\text {nd }}$ Year & 0 & 7.7 & 56.4 & 35.9 \\
$\mathbf{3}^{\text {rd }}$ Year & 10.2 & 69.4 & 4.1 & 16.3 \\
$\mathbf{4}^{\text {th }}$ Year & 1.9 & 7.4 & 44.4 & 46.3 \\
Total & 5.1 & 28.2 & 35.9 & 30.8 \\
\hline
\end{tabular}

Table II - Classification of Risk of Exposure to Xylene

\begin{tabular}{|ccccc|}
\hline & no risk (\%) & little risk (\%) & moderate risk (\%) & much risk (\%) \\
& & & & \\
$\mathbf{1}^{\text {st }}$ Year & 3.3 & 10.0 & 40.0 & 46.7 \\
$\mathbf{2}^{\text {nd }}$ Year & 0 & 0 & 7.0 & 93.0 \\
$\mathbf{3}^{\text {rd }}$ Year & 2.1 & 51.1 & 14.9 & 31.9 \\
$\mathbf{4}^{\text {th }}$ Year & 3.8 & 1.9 & 28.8 & 65.4 \\
Total & 2.3 & 16.3 & 21.5 & 59.9 \\
& & & & \\
\hline
\end{tabular}

Table III - Classification of Risk of Manipulation of Xylene Without Gloves

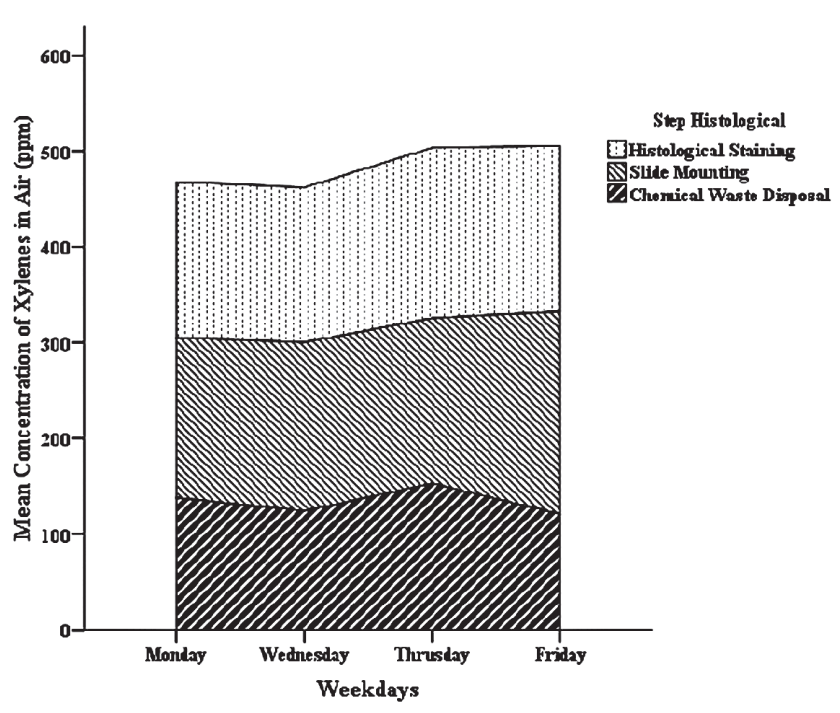

Figure I - Indoor Levels of Xylenes by Weekdays and Histological stage 